\title{
Redesign Spring Bed Based on the Needs of Consumers
}

\author{
Ikhsan Siregar ${ }^{1, a}$, Rosnani Ginting $^{1}$ and Fitri Agnesia ${ }^{1}$ \\ ${ }^{1}$ Department of Industrial Engineering, Faculty of Engineering, University of Sumatera Utara, Jalan Almamater., \\ University of Sumatera Utara, Medan 20155
}

\begin{abstract}
Redesign is needed to evaluate the results of the design before. Completion of the design can be applied to the existing products. Spring bed became one of the human's needs that helps us to sleep well. This research was conducted at a spring bed company based in Medan, Indonesia. Based on preliminary observations, it is known that there are several consumer complaints about spring bed design that exist today. Therefore, we conducted a research to discover the desire of consumers to spring bed design by using Kansei Engineering Method. Questionnaires were distributed to 97 spring bed product consumer, and the results of questionnaires showed that the fifth design was the best design chosen from among 10 existing designs.
\end{abstract}

\section{Introduction}

Design is the act of realizing an idea or concept into the real information. The intense competition in this era of globalization requires companies to design products that match and suitable with consumer expectations.

People in the West region had not paid much attention for their sleeping, people slept on a mattress that placed on top of the spring. Sturdy bed was introduced in the late of 1950s, for the prevention of spinal cord disease, since then, many people began to put wooden boards under their mattress, that became a common solution, but not good enough to fix the property of the bed and may cause ventilation problems.

The desire of the consumers is very important in the development of a product. The products used by a consumer must be related closely to them, the consumer nowadays is getting smarter in consuming a product. Thus the desire of consumers should be the basic of a product improvement design. Studies looking at consumer needs very much to do, including the Bali aromatherapy product development towards personal type users [1]. As well as on research in the automotive audio interface that is designed based on user satisfaction [2]. Then there are also some people saying that the design of the product based on the evaluation forms and perceptions of customers [3]. Thus it is clear that the consumer is playing an important role for the development of the product.

Redesign the product is also very necessary to do, to increase the purchasing ability of consumers. Product development can recycle these products and being survived in the market [4]. Design the product also can be making a new product in development, because of the detailed design and specification detail, thereby generating a new product [5]. Design can also be done on the process and

\footnotetext{
${ }^{a}$ Corresponding author : ikhsan.siregar@usu.ac.id
} 
the equipment, not only limited to products itself [6]. Redesign product also can raise prices, due to factors that are met by consumer satisfaction [7].

This study uses Kansei Engineering Method; this method is also widely used by previous researcher, such as to select the usage of sunglasses that conducted Malaysia [8]. Not only products, Kansei Engineering has also been done on the study, which assesses the satisfaction of service to Indonesian tourists [9]. Then another study presents a method to cope the emotional impact of product attributes in new product development, is also using Kansei Engineering Method [10]. There are other studies that redesign bottle shape, the design of the old bottle had been evaluated and developed through this method [11]. Other studies exist that use Kansei Engineering Method for audio on the eyeglasses [12]. There is even a chocolate snack examines [13]. There are also applied in ceramic souvenirs product manufacture [14].

However, because of there is none spring bed product study before, this study becomes important because Spring bed on of the solutions for a good sleeping equipment. The quality of a human's fitness is strongly influenced by the way the person is rested. If someone resting comfortably and wake up in a fresh condition, then the daily activities could be good and positive.

Based on these problems, companies need to surf the consumers' desire to be done with Kansei Engineering. Kansei Engineering leads us to what he thought about the statement, in which knowledge, emotions, and harmonized desires, people with Kansei is a person full of emotion and passion, and is being able to react quickly and sensitively to something. Kansei Engineering focuses on the perception of an object and thus produce a response. This method combines the feelings and emotions with product development [15].

First type of Kansei Engineering is a fundamental technique of kansei Engineering Methods that use regular process. Everyone can follow the regular process in order to get a conclusion.

\section{Research method}

The experiment was conducted at the spring bed company in Medan, Indonesia. Spring bed as the research object because there are many spring bed companies in Medan and spring bed is a product that fluently purchased by consumers, especially in the Medan City with a population of about 2 million people.

The type of research that being used is survey research to obtain the actual facts regarding customer satisfaction with spring bed products through a questionnaire then get acquired attribute about what point needs to be improved to increase the quality of the product, carried out repair solutions at the company as a form of a repair of the original design.

Spring Bed product attributes that will be examined are:

1. Spring bed elasticity

2. The thickness of the spring bed mattress

3. Spring bed mattress material foam

4. Spring bed backrest material

5. Spring bed foam upholstery material

6. Spring bed color

Closed semantic differential questionnaire distributed to consumers of spring bed products. Engineering samples are used convenience sampling. Large population sizes and numbers are not known with certainty to make the determination of sample size using a technique sample size for proportions. The formula for a large population sample with an unknown amount according to

$$
n=\frac{Z_{\alpha / 2}^{2} p q}{(e)^{2}}=\frac{1,96^{2} \times 0,5 \times 0,5}{(0,1)^{2}}=96,04 \approx 97 \text { Respondents }
$$

Description:

$\mathrm{n}:$ Number of Sample

$z: z$ value with $95 \%$ confidence level, the value of $z=1.96 \%$ (normal distribution table) 
$\mathrm{p}:$ the proportion will be assessed (by 0.5 if the proportion is unknown)

$\mathrm{q}: 1-\mathrm{p}$

$\mathrm{e}:$ error or the maximum error $10 \%$

Steps of First Type of Kansei Engineering are as follows.

1. The first step is the strategy of the company; the company must have a defined concept or strategy for new products. Kansei engineers must utilize this strategy to be applied to new fields.

2. The second step is to collect Kansei words related to new product concept (around 20-30 words Kansei).

3. The third step is the collected Kansei words are going to be arranged at the point Semantic Differential scale 5- or 7-point.

4. The fourth step is to collect samples of the product as a comparison between similar products from different companies and producers (about 10-20 samples).

5. The fifth step is a list of items and categories, items and categories implies the design specifications of product samples collected. All the properties of the products described, for example, an item consists of color, shape, size, brand logos, and others. Categories for example item category colors have yellow, red, green and others.

6. The sixth step is the trial evaluation noted that respondents were asked their feelings with words Kansei for each sample on a sheet of Semantic Differential Scale.

7. The seventh step is analysis, statistically evaluated and analyzed with statistical methods, especially with multivariate statistical analysis.

8. The eight step is the interpretation of the data that being analyzed, that is, all the data is being analyzed to be interpreted from the Kansei Engineering viewpoint. The goal is to find the relationship between human Kansei and product properties. Data that were analyzed every Kansei association was found with the design specifications.

9. The ninth step is Explanation of data, data interpretation must explain to the company's designers to create new designs with the help of a designer.

10. The tenth step of the collaboration of engineers with designers, Kansei motivate the company to create a new product design. This process, engineers design Kansei should support the creation of new products based on the Kansei Engineering data.

\section{Result and analysis}

Stages of data processing with Kansei Engineering begin with determining the decision of strategy is designing products that fit to consumers psychological. Then the collection of Kansei Words derived from the magazine, literature (text book or journal), expert opinions, interviews, namely:

1. Hard-Soft

2. Not Comfortable - Comfortable

3. Not Elegant - Elegant

4. Not Ergonomics - Ergonomics

5. Perishable - Durable

6. Boring - Interesting

7. Not Elastic - Elastic

Validity and reliability tests performed on questionnaires that have been distributed. Testing the validity of the results is shown in Table 1 .

Table 1. Summary of each design validity.

\begin{tabular}{|c|c|c|c|}
\hline Design & Exp-r & Critique-r & Conclusion \\
\hline I & 0.299 & 0,200 & Valid \\
\hline
\end{tabular}




\begin{tabular}{|c|c|c|c|}
\hline II & 0.322 & 0,200 & Valid \\
\hline III & 0.442 & 0,200 & Valid \\
\hline IV & 0.271 & 0,200 & Valid \\
\hline V & 0.375 & 0,200 & Valid \\
\hline VI & 0.404 & 0,200 & Valid \\
\hline VII & 0.278 & 0,200 & Valid \\
\hline VIII & 0.344 & 0,200 & Valid \\
\hline IX & 0.362 & 0,200 & Valid \\
\hline X & 0.409 & 0,200 & Valid \\
\hline XI & 0.299 & 0,200 & Valid \\
\hline
\end{tabular}

Reliability test was conducted by using Cronbach's Alpha, the reliability coefficient values were calculated using Cronbach alpha formula is:

$$
\begin{aligned}
& r=\left(\frac{k}{k-1}\right)\left(1-\frac{\sum \sigma_{b}^{2}}{\sigma_{t}^{2}}\right) \\
& =\left(\frac{10}{10-1}\right)\left(1-\frac{92,701}{120,330}\right) \\
& =0,209
\end{aligned}
$$

$\mathrm{R}$ table value with $\mathrm{n}=97$ and 2 degrees of freedom for a significant level of $5 \%$ is 0.200 , so the questionnaire otherwise reliable. The next step is statistical analysis using conjoint analysis. With the following steps:

a. Determining the constant value

Constant values obtained using the formula with $\mathrm{n}=5$ because of the scale used in the questionnaire SD is a scale of 5.

$$
\begin{aligned}
& c=\left[\frac{1+2+3+\ldots+n}{n}\right] \\
& c=\left[\frac{1+2+3+4+5}{5}\right]=3
\end{aligned}
$$

b. Determine the average value

The average value obtained using the following formula:

$$
\bar{x}=\left[\frac{x_{1}+x_{2}+x_{3}+\ldots+x_{n}}{n}\right]
$$

Sample calculations for the design of the First Kansei Word, hard - soft

$$
\text { Average }=\frac{3+3+4+2+\ldots .+2+5}{97}
$$

$$
=3,278
$$

Statistical analysis recapitulation using conjoint analysis as follows. 
Table 2. Statistical Analysis with Conjoint Analysis

\begin{tabular}{|c|c|c|c|c|c|c|c|}
\hline Design & $\begin{array}{c}\text { Hard } \\
- \\
\text { Soft }\end{array}$ & $\begin{array}{c}\text { Not } \\
\text { Comfortable } \\
- \\
\text { Comfortable }\end{array}$ & $\begin{array}{c}\text { Not } \\
\text { Elegant - } \\
\text { Elegant }\end{array}$ & $\begin{array}{c}\text { Not } \\
\text { Ergonomics - } \\
\text { Ergonomics }\end{array}$ & $\begin{array}{c}\text { Perishable } \\
- \\
\text { Durable }\end{array}$ & $\begin{array}{c}\text { Boring } \\
- \\
\text { Interesting }\end{array}$ & $\begin{array}{c}\text { Not } \\
\text { Elastic } \\
- \\
\text { Elastic }\end{array}$ \\
\hline I & 0.278 & 0.515 & -0.732 & 0.299 & 0.247 & 0.206 & 0.309 \\
\hline II & -0.557 & -0.443 & -0.361 & -0.557 & -0.227 & -0.340 & -0.216 \\
\hline III & -0.021 & 0.165 & 0.021 & -0.134 & 0.052 & -0.010 & -0.113 \\
\hline IV & 0.072 & 0.062 & -0.072 & 0.021 & 0.505 & -0.196 & -0.124 \\
\hline V & 0.247 & 0.588 & 0.485 & 0.320 & 0.134 & 0.536 & 0.588 \\
\hline VI & 0.206 & -0.021 & -0.113 & -0.082 & -0.052 & 0.588 & 0.124 \\
\hline VII & 0.041 & -0.134 & -0.031 & -0.320 & 0.052 & 0.052 & -0.186 \\
\hline VIII & -0.052 & 0.021 & -0.196 & -0.010 & 0.031 & -0.052 & 0.052 \\
\hline IX & 0.175 & -0.113 & 0.216 & 0.082 & 0.247 & 0.216 & 0.278 \\
\hline X & -0.041 & 0.278 & -0.155 & -0.175 & -0.041 & -0.031 & 0.093 \\
\hline
\end{tabular}

Table 2 shown that respondent chosen design $\mathrm{V}$ from the questionnaire that given to them. Based on the recapitulation of the results of statistical tests, the selected design is $\mathrm{V}$ Design with the following attributes.

Table 3. Selected design category

\begin{tabular}{|c|c|c|}
\hline No & Attribute & Information \\
\hline 1 & Elasticity & Elastic \\
\hline 2 & Foam Thickness & Thick \\
\hline 3 & Foam Materials & Polyurethane \\
\hline 4 & Backrest Material & Seat Foam \\
\hline 5 & $\begin{array}{c}\text { Coating Foam } \\
\text { Material }\end{array}$ & Cotton \\
\hline 6 & Color & Brown \\
\hline
\end{tabular}

Table 3 shown respondents chosen selected categories that want to improve based on the existing design. Respondent want more elasticity, more thickness, the material foam is polyurethane, need backrest material foam, the material for coating foam is cotton, and last the color chosen for the new design is brown.

\section{Conclusion}

Based on the Semantic Differential questionnaires that have been distributed, it is known that more consumers want the $\mathrm{V}$ product design, which has attributes: elastic, thick foam, polyurethane foam materials, materials backrest upholstery foam, cotton foam sheathing, and brown. Selected spring bed product design attributes becomes of draft product design improvements that exist today. The result of this design is entirely based on the largest order of choice of consumers obtained through the method of Kansei Engineering. While the conclusions obtained through this research, now the existing entries have been awarded to the company and will be implemented, this is done to see the extent how far the consumer feedback on products that will be designed according to the tastes of the market. 


\section{References}

1. Djatna, Taufik., Balinese aromatherapy product development based on Kansei Engineering and customer personality type, Procedia Manufacturing 4 ( 2015 ) 176 - 183.

2. Gaspar, Jose., User satisfaction modeling framework for automotive audio interfaces, International Journal of Industrial Ergonomics 44 (2014) 662-674.

3. Tang, C.Y., Product form design using customer perception evaluation by a combined superellipse fitting and ANN approach, Advanced Engineering Informatics 27 (2013) 386-394.

4. Aguiar., Jessica de., A design tool to diagnose product recyclability during product design phase, Journal of Cleaner Production 141 (2017) 219-229.

5. Du., Yanbin., Reuse-oriented redesign method of used products based on axiomatic design theory and QFD, Journal of Cleaner Production 39 (2013) 79-86.

6. Fegade, Vishal., Design for Remanufacturing: Methods and their Approaches, Materials Today: Proceedings 2 ( 2015 ) 1849 - 1858.

7. Jiang., Yuanchun, Redesigning promotion strategy fore-commerce competitiveness through pricing and recommendation, Int. J.ProductionEconomics 167(2015)257-270.

8. Chuan, Ngip Khean., Kansei engineering for e-commerce sunglasses selection in Malaysia, Procedia - Social and Behavioral Sciences 97 ( 2013 ) 707 - 714.

9. Hartono, Markus., Incorporating service quality tools into Kansei Engineering in services: A case study of Indonesian tourists, Procedia Economics and Finance 4 ( 2012 ) $201-212$.

10. Huang, Yuexiang., A product configuration analysis method for emotional design using a personal construct theory, International Journal of Industrial Ergonomics 44 (2014) 120-130.

11. Luo, Shi-Jian, A preliminary study of perceptual matching for the evaluation of beverage bottle design, International Journal of Industrial Ergonomics 42 (2012) 219-232.

12. Lu, Weihua., Affective design of products using an audio-based protocol: Application to eyeglass frame, International Journal of Industrial Ergonomics 44 (2014) 383-394.

13. Schütte, Simon. Evaluation of the affective coherence of the exterior and interior of chocolate snacks, Food Quality and Preference 29 (2013) 16-24.

14. Tama, Ishardita Pambudi., Development of customer oriented product design using Kansei engineering and Kano model: Case study of ceramic souvenir, Procedia Manufacturing 4 ( 2015 ) $328-335$.

15. Falk Steinberg, dkk. 2015. The Improvement Of Kansei Engineering By Using The Repertory GridTechnique, Management and Production Engineering Review. 